\title{
Quality Assessment of Marketed Eggs in Bassekabylie (Algeria)
}

Technical Note

-Author(s)

Moula $\mathrm{N}^{*}$

Ait-Kaki $A^{\| *}$

Leroy P'

Antoine-Moussiaux $\mathrm{N}^{\prime}$

Department of Animal Production, Faculty of Veterinary Medicine, University of Liege, Liege 4000, Belgium

" Departement of Biochemistry and microbiology, Faculty of natural sciences, University of Mentouri, Constantine, Algeria.

* Nassim Moula and AsmaAit Kaki contributed equally to this publication.

\section{nMail Adress}

Corresponding author e-mail address Prof. P. Leroy \& Dr. N. Antoine-Moussiaux

E-mail: pascal.leroy@ulg.ac.be

\& nantoine@ulg.ac.be

\section{Eeywords}

Bejaia, consumer channels, egg quality, egg prices, marketed table eggs, egg grades.

\section{ABSTRACT}

Quality variations in retail eggs are widely reported. This study aims at assessing the quality of eggs according to the marketing channel in the department of Bejaia (Algeria). In spring and summer 2012, 3330 eggs were bought in 30 stores divided into 3 categories: 10 supermarkets (1146 eggs), 10 public markets (1048 eggs), and 10 shops (1136 eggs). Egg weights differed significantly between marketing channels with $58.9 \pm 0.14,61.2 \pm 0.13$ and $62.8 \pm 0.13 \mathrm{~g}$ for public markets, shops and supermarkets, respectively $(p<0.001)$. Although shell thickness was similar for all marketing channels, the proportion of damaged eggs was higher in public markets $(9.0 \%)$, intermediate in food shops $(7.3 \%)$ and lower in supermarkets $(5.7 \% ; p<0.05)$. The yolk/albumen ratio was significantly higher for eggs from supermarkets (48.0\%) compared with the other channels (around $47.4 \% ; p<0.05$ ). The freshness of the eggs, measured by the Haugh method, was lower in public markets (74.3 units), intermediate in shops (77.6 units) and higher in supermarkets (79.9 units; $p<0.05$ ). The price of eggs, expressed in Algerian Dinar (AD) per kg, was significantly lower in public markets (124 AD/kg) compared with the two other channels (around $131 \mathrm{AD} / \mathrm{kg} ; \mathrm{p}<0.05$ ). It is possible to conclude that egg quality in Bass Kabylie differs significantly among marketing channels, with higher quality observed in supermarkets. The lower quality of eggs in public markets is associated with lower price. Eggs from shops present an intermediate quality. A one-year study would allow studying both the potential seasonal effect and compare intrinsic variability across marketing channels.

\section{INTRODUCTION}

Hen's eggs have been traditionally considered as an important source of nutrients for humans (Nau et al., 2003). It is a source of proteins, lipids, minerals and vitamins easily renewable. The egg belongs to the limited category of foods containing the nine amino acids that human cannot synthesize. It was thus chosen by World Health Organization (W.H.O.) as the reference protein source for children (reference 100, which is slightly higher than women's milk) (Nys \& Sauveur, 2004). The wide variety of poultry production systems and the low cost price of eggs make them widely accessible to rural and urban population (Moula, 2012). In addition, they are accepted worldwide and are not subject to major cultural or religious prohibitions (Bessadok et al., 2003). Changes in lifestyle and consumption habits, accompanied by the development of the fast food, increased its demand. Indeed, egg proteins are appreciated ingredients in many foods (Mine, 2002).

The production and consumption of eggs in Algeria have undergone a rapid evolution since the 1980s, and continues to increase. Eggs are bought in many different retail spots in Algeria. However, the three 
major channels are supermarkets (urban and peri-urban areas), public markets (in urban centers) and small foodshops (urban, peri-urban and rural areas). The aim of this study was to investigate the quality of eggs offered to the consumers in the department of Bejaia. The egg quality traits taken into consideration were egg weight, freshness (Haugh units), yolk color, shell thickness and yolk/albumen ratio. These characteristics are related to egg production (breed, feeding) and marketing (delay, transport care) features.

\section{MATERIALS AND METHODS}

A total of 3330 eggs were bought from three different marketing channels: 10 supermarkets, 10 public markets and 10 small food shops. The number of analyzed eggs in each source is listed in Table 1.

Table1 - Eggs number by marketing channels and seasons

\begin{tabular}{lcccc}
\hline \multicolumn{5}{c}{ Number of eggs } \\
\hline Season & Total & Food shops & Public markets & Supermarkets \\
\hline Spring & 1624 & 584 & 494 & 546 \\
\hline Summer & 1706 & 552 & 554 & 600 \\
\hline Total & 3330 & 1136 & 1048 & 1146 \\
\hline
\end{tabular}

A random sample was obtained twice from each source at one-week interval during spring and summer. Eggs are mainly sold by batches of 30 units, without any information on the source, laying date, or egg size.

After numbering the eggs, the here-above listed measurements were carried out. Haugh units are an estimate of eggs freshness. These are measured using an electronic scale and a tripod micrometer. Each egg was weighed and broken on a glass surface. The thickness of the albumen was measured with the tripod micrometer, at its maximum height. Haugh units were calculated using the formula described by Haugh (Haugh, 1937): $\mathrm{HU}=100 \log \left(\mathrm{H}-1.7 \mathrm{w}^{0.37}+7.6\right)$; where $\mathrm{HU}=$ Haugh units, $\mathrm{H}=$ Albumen length $(\mathrm{mm})$, $W=$ egg weight (g). Egg yolkcolor was determined using the DSM Yolk Color scale. After removing shell membranes, the thickness of eggshell was measured on three equator points with an electronic micrometer. The average of these three values was considered for data analysis. Tyler and Geake (1964) reported that the eggshell is thinner but almost uniform on equatorial zone. Eggs were graded according to USDA standards in respect to the studied quality components (USDA, 1975). The eggs price per $\mathrm{kg}$ in Algerian Dinar (1DA $\approx$ $0.01 €)$ was also calculated.

The statistical analyses were carried out using SAS software (SAS, 2001).The generalized linear model (GLM) was used to perform an analysis of variance (ANOVA) of each parameter to determine the differences between the three studied retail sources and their statistical significance. For each parameter, the least squares means (LSM) and the standard errors were calculated. The chi-square test was used to test independence between the qualitative variables and retail sources.

\section{RESULTS AND DISCUSSION}

Egg quality is a general term, which refers to several standards that define both internal and external quality. Internal quality refers to egg white (albumen) cleanliness and viscosity, size of the air cell, yolk shape and yolk ratio. Exterior egg quality is defined as texture, color, soundness, cleanliness and shape of the shell. The shell of each egg should be smooth, clean and free from cracks and eggs should be uniform in color, size and shape (Coutts et al., 2006). Egg composition is not a uniform trait and depends on many factors, such as hen breed and egg storage time (Moula et al., 2009; Moula et al., 2010). Variability in the quality of eggs available to consumers has been reported by many investigators (Vanghan and Adams, 1959; Abo Omar \& Aref, 2000; Bell et al., 2001). However, little is known about the quality of eggs commercialized in Algeria.

The statistical analysis showed a significant effect of the retail type on egg weight, Haugh unit, shell thickness and price per $\mathrm{kg}(p<0.05)$. The season and the interaction between marketing channel and season had no significant effect on egg quality traits ( $p>0.05)$ except for egg weight $(p<0.05)$. The season significantly impacted Haugh units $(p<0.001)$, shell thickness $(p<0.0001)$ and price per $\mathrm{kg}(p<0.05)$. Marketing channels significantly influenced egg weight $(p<0.0001)$, Haugh unit $(p<0.0001)$, shell thickness $(p<0.01)$ and Y/A ratio $(p<0.05)$. The eggs bought in supermarkets were significantly heavier than those bought in small foodshops and public markets $(p<0.05)$. However, the price per $\mathrm{kg}$ was not significantly different between shops and supermarkets (Table 2). The difference of egg weight according to marketing channel was observed in this study (Table 2). Consistent findings were previously obtained by Abo Omar \& Aref (2000) and by North (1984), but these authors reported that eggs from shops and public markets were significantly $(p<0.01)$ heavier when compared to supermarkets.

Algeria is a Mediterranean country with a hot summer. This explains the influence of season on egg 
Table 2 - Least Squares Means and standard errors of egg weight, Haugh unit, yolk color, yolk/albumen ratio, shell thickness and price per $\mathrm{kg}$.

\begin{tabular}{|c|c|c|c|c|c|c|c|c|}
\hline & Season & Food Shops & Public markets & Supermarkets & Season & $\begin{array}{l}\text { Marketing } \\
\text { Channels }\end{array}$ & $C * S$ & $\mathrm{R}^{2}$ \\
\hline \multirow[t]{3}{*}{ Egg weight (g) } & Spring & $60.75 \pm 0.19^{\mathrm{a} 1}$ & $59.40 \pm 0.20^{\mathrm{b} 1}$ & $62.74 \pm 0.19^{c 1}$ & \multirow[t]{2}{*}{ ns } & \multirow[t]{2}{*}{$* * *$} & \multirow[t]{2}{*}{$\star * \star$} & \multirow[t]{2}{*}{.11} \\
\hline & Summer & $61.71 \pm 0.19^{\mathrm{a} 2}$ & $58.53 \pm 0.19^{\mathrm{b} 2}$ & $62.91 \pm 0.19^{c 1}$ & & & & \\
\hline & Total & $61.22 \pm 0.13^{a}$ & $58.94 \pm 0.14^{b}$ & $62.83 \pm 0.13^{c}$ & & & & \\
\hline \multirow{3}{*}{$\begin{array}{l}\text { Y/A } \\
\text { ratio }\end{array}$} & Spring & $47.58 \pm 0.15^{\mathrm{ab} 1}$ & $47.36 \pm 0.16^{b 1}$ & $47.85 \pm 0.16^{\mathrm{a} 1}$ & \multirow[t]{3}{*}{ ns } & \multirow[t]{2}{*}{ * } & \multirow[t]{2}{*}{ ns } & \multirow[t]{2}{*}{.01} \\
\hline & Summer & $47.01 \pm 0.16^{\mathrm{a} 2}$ & $47.69 \pm 0.16^{b 1}$ & $48.11 \pm 0.15^{\mathrm{b} 1}$ & & & & \\
\hline & Total & $47.31 \pm 0.11^{\mathrm{a}}$ & $47.53 \pm 0.11^{\mathrm{a}}$ & $47.98 \pm 0.11^{\mathrm{b}}$ & & & & \\
\hline \multirow[t]{3}{*}{ Haugh unit } & Spring & $81.97 \pm 0.60^{\mathrm{a} 1}$ & $79.13 \pm 0.65^{b 1}$ & $81.53 \pm 0.58^{\mathrm{a} 1}$ & \multirow[t]{2}{*}{$* * *$} & \multirow[t]{2}{*}{$\star * *$} & \multirow[t]{2}{*}{$* * *$} & \multirow[t]{2}{*}{.09} \\
\hline & Summer & $72.90 \pm 0.61^{\mathrm{a} 2}$ & $69.91 \pm 0.61^{\mathrm{b} 2}$ & $78.46 \pm 0.59^{c 2}$ & & & & \\
\hline & Total & $77.56 \pm 0.44^{a}$ & $74.26 \pm 0.46^{b}$ & $79.92 \pm 0.44^{c}$ & & & & \\
\hline \multirow[t]{3}{*}{ Yolk color } & Spring & $11.04 \pm 0.07^{\mathrm{a} 1}$ & $11.15 \pm 0.07^{a b 1}$ & $11.23 \pm 0.07^{\mathrm{b} 1}$ & \multirow[t]{2}{*}{ ns } & \multirow[t]{2}{*}{ ns } & \multirow[t]{2}{*}{ * } & \multirow[t]{2}{*}{.01} \\
\hline & Summer & $11.34 \pm 0.07^{\mathrm{a} 2}$ & $11.01 \pm 0.07^{\mathrm{b} 1}$ & $11.24 \pm 0.06^{\mathrm{a} 1}$ & & & & \\
\hline & Total & $11.19 \pm 0.05^{\mathrm{ab}}$ & $11.07 \pm 0.05^{b}$ & $11.23 \pm 0.05^{\mathrm{a}}$ & & & & \\
\hline \multirow{3}{*}{$\begin{array}{l}\text { Shell thickness } \\
(.01 \mathrm{~mm})\end{array}$} & Spring & $37.36 \pm 0.16^{\mathrm{a} 1}$ & $37.45 \pm 0.17^{\mathrm{a} 1}$ & $38.06 \pm 0.17^{\mathrm{b} 1}$ & \multirow[t]{2}{*}{$* * *$} & \multirow[t]{2}{*}{ ** } & \multirow[t]{2}{*}{ ns } & \multirow[t]{2}{*}{.02} \\
\hline & Summer & $36.28 \pm 0.17^{\mathrm{a} 2}$ & $36.80 \pm 0.17^{\mathrm{b} 2}$ & $36.91 \pm 0.16^{\mathrm{b} 2}$ & & & & \\
\hline & Total & $36.84 \pm 0.12^{\mathrm{a}}$ & $37.11 \pm 0.12^{\mathrm{a}}$ & $37.46 \pm 0.12^{\mathrm{a}}$ & & & & \\
\hline \multirow[t]{3}{*}{ Price/kg (DA) } & Spring & $131.75 \pm 3.62$ & $123.47 \pm 3.62$ & $130.77 \pm 3.62$ & \multirow[t]{2}{*}{ * } & \multirow[t]{2}{*}{ ns } & \multirow[t]{2}{*}{ ns } & \multirow[t]{2}{*}{.32} \\
\hline & Summer & $126.71 \pm 3.62^{b}$ & $124.03 \pm 3.62^{b}$ & $135.26 \pm 3.62^{a}$ & & & & \\
\hline & Total & $129.23 \pm 2.53^{\mathrm{a}}$ & $123.75 \pm 2.53^{b}$ & $133.02 \pm 2.53^{\mathrm{a}}$ & & & & \\
\hline
\end{tabular}

Means followed by the same letter $(a, b, c)$ in the same row are notstatistically different ( $p$-value $>0.05)$. Means followed by the same number $(1,2)$ in the same columnare not statistically different (p-value $>0.05){ }^{* * *}: p<0.0001 ;{ }^{* *}: p<0.001 ;{ }^{*}: p<0.05 ;$ NS: $p>0.05$. Season: S; Marketing Channels : C.

quality (Table 2), especially on their freshness (HU units). In fact, egg freshness was significantly higher in spring. The same result was found by Islam et al. (2001). Thus, under high temperature conditions, egg production and egg quality decrease (Leeson, 1986) and one of the reasons of these detrimental effects is insufficient feed intake (Leeson and Summers, 1997). Eggs sold in supermarkets in this study, presented the best quality, considering their freshness. In addition, their freshness was higherthan those sold in supermarkets of California (HU: 61.1), Illinois (HU: 62.8), Pennsylvania
(64.0), Texas (HU: 59.6), North Carolina (HU: 67.7) and New England (HU: 68.1), as described by Bell et al. (2001). No significant effect of marketing channel on the egg price per $\mathrm{kg}$ was observed in the study of Abo Omar et al. (2000). However, here, the price of eggs in public markets was significantly lower compared with other marketing sources.

Eggweight categories are shown in Table 3. These categories were clustered according to the European classification. The chi-square test showed a significant link between weight classes and marketing channels

Table 3 - Distribution (\%) of weight classes

\begin{tabular}{|c|c|c|c|c|c|c|}
\hline \multirow{2}{*}{$\begin{array}{l}\text { Egg weight } \\
\text { classes }^{1}\end{array}$} & \multirow[t]{2}{*}{ Season } & \multicolumn{3}{|c|}{ Consumer Channels } & \multirow[t]{2}{*}{ Mean } & \multirow[t]{2}{*}{ Statistical Significance } \\
\hline & & Foodshops & Public markets & Supermarkets & & \\
\hline \multirow[t]{3}{*}{ Extra-large } & Spring & 0.86 & - & 14.47 & 5.17 & $\star \star \star *$ \\
\hline & Summer & 1.63 & 2.89 & 4.83 & 3.17 & $* * *$ \\
\hline & Total & 1.23 & 1.53 & 9.42 & 4.14 & $* * *$ \\
\hline \multirow[t]{3}{*}{ Large } & Spring & 20.03 & 12.15 & 25.46 & 19.46 & $* * *$ \\
\hline & Summer & 28.80 & 14.62 & 35.50 & 26.55 & $\star \star \star$ \\
\hline & Total & 24.30 & 13.45 & 30.72 & 23.09 & $* * *$ \\
\hline \multirow[t]{3}{*}{ Medium } & Spring & 76.71 & 78.95 & 60.07 & 71.80 & $* * *$ \\
\hline & Summer & 69.57 & 67.69 & 59.67 & 65.47 & $* * *$ \\
\hline & Total & 73.24 & 73.00 & 59.86 & 68.56 & $\star * \star$ \\
\hline \multirow[t]{3}{*}{ Small } & Spring & 2.40 & 8.91 & - & 3.57 & $* * *$ \\
\hline & Summer & - & 14.80 & - & 4.81 & $\star * \star$ \\
\hline & Total & 1.23 & 12.02 & - & 4.20 & $* * *$ \\
\hline
\end{tabular}


Table 4 - Distribution (\%) of damaged eggs according to the marketing channels.

\begin{tabular}{|c|c|c|c|c|c|c|}
\hline \multirow[t]{2}{*}{ Damaged eggs } & \multirow[t]{2}{*}{ Season } & \multicolumn{3}{|c|}{ Consumer Channels } & \multirow[t]{2}{*}{ Mean } & \multirow[t]{2}{*}{ Statistical Significance } \\
\hline & & Food shops & Public markets & Supermarkets & & \\
\hline \multirow{3}{*}{$\%$} & Spring & 5.14 & 12.75 & 5.13 & 7.45 & $\star * *$ \\
\hline & Summer & 9.60 & 5.60 & 6.17 & 7.09 & * \\
\hline & Total & 7.31 & 8.97 & 5.67 & 7.27 & * \\
\hline
\end{tabular}

$(p<0.05)$. Most of the eggs bought were mediumsized. In the supermarkets, nearly $10 \%$ of eggs were extra-large. This category represented less than $2 \%$ of eggs in public markets and foodshops (Table 3 ).

The proportion of damaged eggs was higher in public markets $(9.0 \%)$, intermediate in food shops $(7.3 \%)$ and lower in supermarkets $(5.7 \% ; p<0.05)$ (Table 4).

Haugh units were significantly lower in eggs sold in public markets, indicating that eggs were not very fresh $(p<0.05$; Table 3$)$. This result may be explained by the exposure of eggs to air. Storage conditions, including temperature, humidity, presence of $\mathrm{CO}_{2}$, and duration of storage, are also of prime importance for egg quality at retail (Samli et al., 2005). Storage time and temperature appear to be the most crucial factors affecting albumen quality or Haugh unit (HU). A high percentage of the analyzed eggs were AA grade,i.e., according toUSDA norms (USDA, 1975) concerning interior quality (Table 5). Yolk color of eggs obtained in different marketing channels was not different, which can be explained by the uniformity of the feed used in poultry farming in Algeria.

As a conclusion, marketing channel significantly influences eggs quality in Bass Kabylie, with higher quality observed in eggs sold in supermarkets. The lower quality of eggs bought in public markets is associated with their lower price. Nevertheless, this lower price should not automatically be ascribed to the lower quality. Rather, the shorter marketing chains may provide a better explanation. For most of the parameters, eggs from small food shops present intermediate values. Accordingly, this study indicates to the need of quality improvements in short marketing chains. The promotion of such local markets would provide outlets for eggs of local breeds and promote the preservation of biodiversity and inclusive rural development.

\section{REFERENCES}

Abo Omar JM, Aref RO. Some quality characteristics of eggs marketed in North of West Bank (Palestine). Revue de Médecine Vétérinaire 2000;151:47-50.

Bell DD, Patterson PH, Koelkebeck KW, Anderson K E, Darre M J, Carey J B, Kuney DR, Zeidler G. Egg Marketing in National Supermarkets: Egg Quality_Part 1. Poultry Science 2001; 80:383-389.

Bessadok A, Khochilef I, El Gazzah M. Etat des ressources génétiques de la population locale du poulet en Tunisie. Tropicultura 2003;21:167-172.

Coutts JA, Wilson GC, Fernandez S, Rasales E, Weber G, Hernandez JM. Optimum Egg Quality - A Practical Approach. Shefield: 5M Publishing; 2006. p.63

Haugh RR. The Haugh unit for measuring egg quality. U.S. Egg poultry Magazine 1937;43: 522-573

Islam MA, Bulbul SM, Seeland G, Egg Quality of Different Chicken Genotypes in Summer and Winter. Pakistan Journal of Bioligical Sciences 2001; 4:1411-1414

Leeson S, Summers JD. Feeding programs for laying hens. Guelph: Commercial Poultry Nutrition; 1997.p.143-206.

Table 5 - Haugh unit values and grade distribution (\%) of eggs according to the marketing channels.

\begin{tabular}{|c|c|c|c|c|c|c|c|}
\hline \multirow{3}{*}{$\begin{array}{l}\text { Haugh } \\
\text { unit value }\end{array}$} & \multirow{3}{*}{$\begin{array}{l}\text { USDA } \\
\text { grade }\end{array}$} & \multirow[t]{3}{*}{ Season } & \multicolumn{5}{|c|}{ Distribution of weight classes (\%) } \\
\hline & & & \multicolumn{3}{|c|}{ Marketing Channels } & \multirow[t]{2}{*}{ Mean } & \multirow[t]{2}{*}{ Statistical Significance } \\
\hline & & & Foodshops & Public markets & Supermarkets & & \\
\hline \multirow[t]{3}{*}{$>72$} & \multirow[t]{3}{*}{ AA } & Spring & 69.69 & 62.75 & 76.92 & 70.01 & *** \\
\hline & & Summer & 18.23 & 47.29 & 65.50 & 56.62 & $\star \star \star$ \\
\hline & & Total & 63.20 & 54.58 & 70.94 & & \\
\hline \multirow[t]{3}{*}{$60-72$} & \multirow[t]{3}{*}{ A } & Spring & 22.09 & 16.40 & 16.30 & 18.41 & $\star * \star$ \\
\hline & & Summer & 25.00 & 23.10 & 24.00 & 24.03 & *** \\
\hline & & Total & 23.50 & 19.94 & 20.33 & & \\
\hline \multirow[t]{3}{*}{$31-60$} & \multirow[t]{3}{*}{ B } & Spring & 8.05 & 17.61 & 6.78 & 10.53 & *** \\
\hline & & Summer & 18.30 & 26.71 & 10.50 & 18.29 & $\star * *$ \\
\hline & & Total & 13.03 & 22.42 & 8.73 & & \\
\hline \multirow[t]{3}{*}{$<31$} & \multirow[t]{3}{*}{ C } & Spring & 0.17 & 3.24 & - & 1.05 & $\star * *$ \\
\hline & & Summer & 0.36 & 2.89 & - & 1.06 & *** \\
\hline & & Total & 0.26 & 8.73 & - & & \\
\hline
\end{tabular}


Leeson S. Nutritional consideration of poultry during heat stress. World's Poultry Science Journal 1986;42:69-79.

Mine $Y$. Recent advances in egg protein functionality in the food system. World's Poultry Science Journal 2002; 58: 31-39.

Moula N, Antoine-Moussiaux N, Farnir F, Leroy P. Comparison of Egg Composition and Conservation Ability in Two Belgian Local Breeds and One Commercial Strain. International Journal of Poultry Sciences 2009;8:768-774

Moula N, Antoine-Moussiaux N, Decuypere E, Farnir F, Mertens K, De Baerdemaeker J, Leroy P. Comparative study of egg quality traits in two Belgian local breeds and two commercial lines of chickens. Archiv Fuer Gefluegelkunde 2010;74:164-171.

Moula N.Biodiversité avicole dans les pays industrialisés et en développement: caractérisation et étude des performances de production de races gallines locales. Liége: Presses de la Faculté de Médecinevétérinaire de I'Université de Liège; 2012. 261p.

Nau F, Anton M, Nys Y. L'œuf de poule: une mine de molécules a activitésbiologiques. Cinquièmes Journées de la Recherche Avicole; 2003 Mar 26-27; Tours.

North MO. Commercial chicken production manual. Connecticut: AVI Publishing; $1984.710 \mathrm{p}$.

Nys $Y$, Sauveur B. The nutritional value of eggs. INRA Productions Animales 2004;17:385-393.

Samli HE, Agma A, Senkoylu N. Effects of Storage Time and Temperature on Egg Quality in Old Laying Hens. The Journal of Applied Poultry Research 2005; 14:548-553.

SAS INSTITUTE. SAS/STAT user's guide. Version 9. Cary, NC; 2001.

Tyler C, Geake FH. Eggshell strength and its relationship to thickness, with particular reference to individuality in the domestic hen. British Poultry Science 1964:5:3-18.

USDA. Egg grading manual. Washington: Agricultural Marketing Services, 1975.

Vanghan MC, Adams JL. Quality of eggs offered to consumers in Lincoln, Nebraska. Poultry Science 1959;38:1257 
